\title{
СУЧАСНИЙ СТАН ОРГАНІЗАЩІЇ ЕКОЛОГІЧНИХ ТА АГРОРЕКРЕАЦІЙНИХ ПОСЕЛЕНЬ ТА ПЕРСПЕКТИВИ ЇХ РОЗВИТКУ
}

\author{
Myxa T. O., аспірант \\ Шулик В. В., д.арх., проф. \\ Украӥна, м. Харків \\ Харківський національний університет міського господарства імені О.М. Бекетова
}

DOI: https://doi.org/10.31435/rsglobal_ws/30082018/6051

\section{ARTICLE INFO}

Received: 13 July 2018

Accepted: 27 August 2018

Published: 30 August 2018

\section{KEYWORDS}

ecological settlements, agro-recreational, sustainable development, landscapes, network. \begin{abstract}
The article is devoted to the study of existing ecological settlements with agro-recreational function in domestic and foreign practice, which are an integral part of recreational areas and are in interaction with all components of the recreational environment.

In modern conditions, urbanization has become more global. Growth of settlements, increasing the proportion of urban population, as well as the emergence of more complex networks and systems of cities - has led to an expansion of the habitats of the urban environment and their qualitative changes.

Agri-environmental use in modern conditions of sustainable development should ensure not only ecological food products for the population, but also guarantee the ecological development of the agroindustrial complex at the economic and urban levels, without prejudice to the natural environment.

The solution of the problem in general is to create agro-recreational ecological settlements for their inclusion in recreational systems, by creating agrarian landscapes, using the main recreational resources of urban and rural areas such as climate, microclimate, relief, surrounding landscapes, etc.
\end{abstract}

Citation: Муха Т. О., Шулик В. В. (2018) Suchasnyi Stan Orhanizatsii Ekolohichnykh ta Ahrorekreatsiinykh Poselen ta Perspektyvy Yikh Rozvytku. World Science. 8(36), Vol.1. doi: 10.31435/rsglobal_ws/30082018/6051

Copyright: (c) 2018 Муха Т. О., Шулик В. В. This is an open-access article distributed under the terms of the Creative Commons Attribution License (CC BY). The use, distribution or reproduction in other forums is permitted, provided the original author(s) or licensor are credited and that the original publication in this journal is cited, in accordance with accepted academic practice. No use, distribution or reproduction is permitted which does not comply with these terms.

Вступ. Стаття присвячена дослідженню існуючих екопоселень 3 агрорекреаційною функцією у вітчизняній та зарубіжній практиці, які $\epsilon$ невід'ємною складовою частиною рекреаційних районів і знаходяться у взаємодії з усіма компонентами рекреаційного середовища.

В умовах сучасності урбанізація набула більш глобальних розмірів. Зростання населених пунктів, підвищення питомої ваги міського населення, а також виникнення більш складних мереж та систем міст - призвело до розширення ареалів урбанізованого середовища та їх якісних змін.

Агрорекреаційне природовикористання в умовах сталого розвитку повинно забезпечувати не тільки екологічну продовольчу продукцію для населення, а й гарантувати екологічний розвиток агропромислового комплексу на економічному та містобудівному рівнях без шкоди природному середовищу.

Рішення проблеми в загальних рисах полягає в формуванні агрорекреаційних екопоселень для включення їх в рекреаційні системи, шляхом створення агрорекреаційних ландшафтів, максимально використовуючи основні рекреаційні ресурси територій, такі як клімат, мікроклімат, рельєф, навколишні ландшафти тощо. 
Результати дослідження. Дослідження агрорекреаційних екопоселень на основі системного підходу представляється у вигляді їх моделювання на різних ієрархічних рівнях: макрорівень, мезорівень, мікрорівень.

При цьому на макрорівні аналіз агрорекреаційних екопоселень ведеться на основі географічних методів та методах районного планування, а на мезо- і макрорівнях - на основі методів районного планування та містобудування.

На макрорівні в даній роботі досліджуються поселення в межах формування адміністративних районів / об'єднаних територіальних громад та області, на мезорівні - проводиться аналіз досвіду проектування окремих населених пунктів 3 даної тематики, на мікрорівні - аналіз структурних компонентів поселення. Для кожного ієрархічного рівня проводиться аналіз зарубіжного та вітчизняного досвіду формування агрорекреаційних екопоселень окремо.

Прикладом зарубіжного досвіду формування агрорекреаційних екорайонів $є$ проект «Агроатрактивний район» Університету штату Небраска-Лінкольн (University of Nebraska-Lincoln) [1], розроблений вздовж екологічного коридору між містами Лінкольн та Омаха. Проектом пропонується максималізація органічного сільськогосподарського виробництва шляхом створення просторових модулів, які включають в свою структуру житло та територію органічного сільського господарства. Агроатрактивний район займає площу близько 18000 гектарів, з яких 10000 присвячених рослинницької продукції. Кількість ділянок становить 3164 одиниць 3 середнім розміром близько 1,6 гектарів для одного будинку. У складі кожного модуля є 30 житлових будинків зі своєю прибудинковою територією та агротериторія певного профілю 3 необхідними господарчими спорудами. Цей приклад можливо використовувати для рівнинних ділянок, в умовах складного рельєфу модульне формування агрорекреаційних екотериторій буде проблемним.

Державна «Програма сталого розвитку села на 2011-2015 рр.» для агромістечок Білорусії заснована на екологічних напрямках проектування населених пунктів. Для сталого розвитку сільського поселення збільшується трудовий потенціал та розвивається житлова та соціальна сфери поселення. Враховується також екологічний показник території, збільшення якого призводить до покращення здоров'я населення і збільшення якості сільськогосподарської продукції.

Прикладом вітчизняного досвіду формування рекреаційних територій на макрорівні може бути той, що представлений в науково-дослідній роботі «Розвиток туристичнорекреаційної системи Полтавської області». В даному дослідженні відповідно до «Схеми розвитку і розміщення курортів, місць відпочинку і туризму, природних парків і заповідників в Україні» (Київ, НДПІмістобудування, 1983р.) одноразова місткість вітчизняних ландшафтів України потенційно може становити близько 49 млн. чол.

Потенційна місткість природних рекреаційних ресурсів для організації зон відпочинку та освоєння курортних місцевостей може скласти 16,3 млн. чол. при орієнтації на використання природних ландшафтів 28,9 млн. чол. при відповідному їхньому благоустрою.

Розрахунок нормативних потреб населення Полтавської області в різних видах і формах рекреації проведений шляхом визначення кількості одночасно відпочиваючих жителів всіх міських поселень на основі відповідних показників диференційованих щодо умов проживання в населених місцях різної величини. Розрахунками визначені кількість рекреантів на існуючий період (станом на 2012 р) та на розрахунковий строк (до 2036 р). Розрахунки проведено на основі «Прогнозу чисельності та статево-вікового складу населення Полтавської області до 2036 р.», виконаного Інститутом демографії та соціальних досліджень НАН України ім. М. В. Птухи у 2012 році.

Для формування системи відпочинку i туризму визначення рекреаційної ємності території $\epsilon$ одним 3 головних завдань. Для цього, враховуючи ландшафтно-кліматичні особливості Полтавщини, а також спираючись на методичні рекомендації [2], проведені розрахунки рекреаційної ємності території Полтавської області. За рекреаційну ємність території прийнята ємність ділянок, які є та можуть бути привабливими для відпочинку та туризму.

Згідно даних про лісистість Полтавської області в розрізі адміністративних одиниць найбілыша площа лісовкритих земель у відсотковому співвідношенні визначена у Котелевському районі (21,3\% від загальної площі району). Найбільше ставків і малих водосховищ на території Глобинського району (161), найменше - Котелевського (8) й Кобеляцького районів (7).

Ще однією складовою частиною рекреаційної ємності є колективні сади та дачі, які передбачені, як для короткочасного так і для довгострокового відпочинку. Територія яких (за даними, наданими Управлінням містобудування та містобудування та архітектури Полтавської облдержадміністрації, форми 2 3ЕМ) складає 372,31 га, кількість відпочиваючих складе 11 тис. осіб, з яких короткочасно відпочиваючі складають 6,7 тис. осіб, а довгострокові - 4,4 тис. осіб. Найбільший відсоток площі садових та дачних ділянок у Карлівському, Машівському та Лубенському районах. Відповідно дефіцит подібного типу рекреаційних утворень існує в Зінківському, Котелевському, Гадяцькому, Шишацькому, Козельщинському, Лохвицькому, Семенівському та Чорнухівському районах. 
Полтавщина $є$ однією з областей України, де пам'ятки археології за своєю чисельністю та кількістю значно перевищують показники щодо інших категорій об'єктів культурноісторичної спадщини. На її просторах розкидані до 10 тис. курганів, близько сотні стародавніх городищ, розташовані залишки первісних міст-держав доби раннього залізного віку, 3 яких найбільшим $€$ пам'ятка світового значення - Більське городище скіфської доби - залишки міста Гелона, відомого за описом Скіфії “батька історії” - давньогрецького вченого V ст. до н. е. Геродота (Котелевський район).

Відповідно до вищезазначеного аналізу найбільш перспективним для розвитку мережі агрорекреаційних екопоселень $є$ Котелевський, Миргородський та Шишацький райони. Отже, в цих районах найбільш актуальними стають питання з формування агрорекреаційних екопоселень для включення їх в рекреаційні системи, шляхом створення агрорекреаційних ландшафтів, максимально використовуючи основні рекреаційні ресурси територій міського та сільського середовища.

Для мезо- та мікрорівня даного дослідження проведено аналіз формування екопоселень та населених пунктів з агрорекреаційною функцією.

В даний час розроблені різні класифікації екопоселень і їх принципи. Основу класифікації вітчизняних екопоселень становить їх внутрішня ідеологія, або мета. Аналіз теоретичних основ i зарубіжного досвіду кращих світових практик показує, що містоутворюючою основою переважної частини екопоселень стає широке коло діяльності: різні галузі сільського господарства, народні ремесла, охорона природи, екотуризм, курортносанаторні послуги, наука, екологічна освіта та просвіта. Багато екопоселень було створено для забезпечення роботи національних парків і заповідників.

Ознайомлення з базою даних GEN (2018 року) дозволяє виділити наступні типи екопоселень [3]:

- Міські екопоселення;

- Аграрні екопоселення;

- Міжнародні об'єднання;

- Екологічні поселення;

- Традиційні сільські екопоселення;

- Трейлерні селища;

- Пермакультурні місця;

- Міста, що змінюються;

- Освітні центри;

- Центри екотуризму.

Ознайомлення з базою даних «poselenia.ru/» (2018 року) дозволило оцінити стан розвитку екопоселень на території України. Виявлено 39 подібних населених пунктів 3 середньою кількістю постійних мешканців близько 20 осіб, а середньою площею на одну сім'ю близько 1,39 га.

Необхідність залучення нових ресурсів в сферу рекреаційної діяльності, а також зростання кількості міських та сільських жителів, які віддають перевагу відпочинку в умовах традиційного сільського середовища, разом із іншими факторами, обумовили розвиток широкої мережі малих населених пунктів, які поєднують рекреаційну та сільськогосподарську функції.

Значна увага приділена проблемі рекреаційного використання малих населених пунктів за кордоном, що знайшло достатньо широке відображення в літературі та в проектній практиці. За даними Гур'янової Г.А. [4], в Польщі нараховується 814 поселень 3 рекреаційною функцією, в яких є 76 тисяч місць для відпочинку. У Франції кількість відпочиваючих в «рекреаційних селищах» дорівнює кількості відпочиваючих в приморських курортах, в селищах Австрії до послуг відпочиваючих 300 тисяч кімнат.

В Болгарії, яка $є$ багатою на пам'ятники історії та культури, на практиці вирішуються питання, пов'язані з організацією на базі сільських населених місць рекреаційних об'єктів, туристичних центів. Загальна концепція архітекторів Болгарії $[5,6]-$ використання поселень 3 наявністю пам'ятників народного зодчества, максимальне збереження історичного архітектурного середовища зі створенням комфортних умов для рекреантів. Архітектура нових забудов в таких поселеннях вирішується в традиційних формах, невеликої поверховості. Сельбищна зона постійного населення розміщується безпосередньо в рекреаційному поселенні або виноситься в інші населені пункти.

Питання використання поселень для потреб відпочиваючих шляхом виділенню житлових площ в індивідуальному житловому фонді розглядають архітектори Польщі [7, 8]. В проекті генплану Котлинського воєводства враховано вимогу ефективного використання існуючих територій, намічено створення на базі неперспективних сільських поселень комплексів щоденного, щотижневого та довготривалого відпочинку. Подібними умовами характеризуються приблизно 300 польських сіл, які, частково втрачаючи свою сільськогосподарську функцію, зберігають житловий фонд, в зв’язку з чим і вирішується задача зміни їх функції в майбутньому, визначення нового способу їх використання, в тому числі і як агрорекреаційних екопоселень. 
В Чехії та Словаччині ставиться питання про залучення ряду поселень для організації довготривалого відпочинку шляхом використання житлового фонду населених місць, а також при будівництві дач на території сільських поселень. Структура сільських поселень тут характеризуються високою щільністю малих сіл з чисельністю мешканців в них до 350 осіб та відстанню між ними 2-3 км. Постановка задачі використання частини 3 них для рекреації пов'язана 3 необхідністю рішення проблеми сімейного відпочинку, популярність якого все більше росте та викликає до життя явище стихійного розвитку дачних поселень. Це призводить до порушення природного середовища, городяни позбавляються озеленених територій загального користування, в дачних поселеннях погіршуються санітарно-гігієнічні умови. Високий попит на сімейний відпочинок може бути покритий шляхом розміщення відпочиваючих 3 дітьми в сільських населених пунктах, які перетворені переважно в дачні. Питання розміщення об’єктів відпочинку в селах Чехії вирішуються і на стадії районного планування. Так, в схемі планування Хрудимського району (інженери Л. Нємец, К. Кабіц) виділені селища спеціального призначення для створення в них нових комплексів відпочинку. Визначено місце цих селищ в системі розселення району, транспортний зв'язок з рекреантами.

Аналіз сучасного стану та тенденцій розвитку агрорекреаційних сіл показав, що при формуванні просторової структури сіл, які поєднують рекреаційну та сільськогосподарську функції, зберігає свою дієвість ряд принципів, які властиві звичайним аграрним поселенням. Однак села рекреаційного напрямку мають більш складну функціональну організацію, яка потребує спеціального дослідження закономірностей формування їх раціональної просторової структури.

У вітчизняній проектній практиці відпрацьовані прийоми планування та забудови заміських рекреаційних установ та їх комплексів. Деякі 3 таких прийомів можуть бути використані для збагачення архітектурно-художнього обліку поселення агрорекреаційного направлення. Однак прогресивний досвід в умовах регіону використовується не в повну міру. Забудова установ відпочинку ведеться, переважно, за спрощеними (за вартістю) проектами, що знижує їх атрактивність. В проектах переважає розосереджена планувальна схема, в зв'язку 3 чим цінні території використовуються неефективно.

Для ліквідування недоліків в плануванні та забудові зон рекреаційної забудови агрорекреаційних поселень необхідно виявити номенклатуру установ відпочинку, які найбільш прийнятні для розміщення в сільській місцевості та малих населених пунктах, особливості їх планувальної організації та архітектури.

Тому 3 всієї кількості теоретичних праць найбільший інтерес викликають ті, які присвячені плануванню та забудові невеликих рекреаційних установ та комплексів. В роботі Лук'янової Л.Г та Цибуха В.І. досліджена цілеспрямована організація простору рекреаційних комплексів з урахуванням різних видів і форм рекреаційної діяльності. Розглянуто види рекреаційних комплексів та їх планувальна організація відповідно до заданої функціональної програми лікування, відпочиноку, туризму. Викладено принципи і прийоми функціональнотехнологічної організації рекреаційних установ.

Вивчення проектів районного планування, натурні дослідження малих населених пунктів дозволили виділити на території Полтавської області більш ніж 51 сформованих поселень даного типу та більш ніж 29 сіл, в яких передбачається розміщення установ відпочинку. В процесі досліджень виявлено ще близько 22 населених пунктів (в основному малих сіл), перспективних для рекреаційного використання.

Незважаючи на різноманітність конкретних містобудівних ситуацій, виявлена певна динаміка в розвитку просторової структури населених пунктів 3 агрорекреаційною функцією, яка дозволяє виділити наступні етапи (рис.1):

I етап. Зародження рекреаційного утворення поряд 3 населеним пунктом або на його території, початок формування нової функціональної зони - зони рекреаційної забудови.

II етап. Територіальний розвиток виробничої та сельбищної зон, а також ділянки рекреаційної забудови, виникнення території регульованого природного ландшафту. Утворення змішаних функціонально зон.

III етап. Виникнення протиріч в розвитку господарчої та рекреаційної функцій населеного пункту.

Сформовані агрорекреаційні поселення знаходяться, в основному, на третьому етапі розвитку та потребують, в зв'язку з цим, грунтовних архітектурно-планувальних заходів 3 врегулювання їх функціонально-планувальної структури. Однак спостерігається в практиці роздільне проектування поселень та розташованих поряд 3 ними установ відпочинку, що призводить до того, що планування рекреаційних утворень вирішуються без врахування сформованої архітектурно-планувальної структури межуючих 3 ними поселень, а при плануванні малих населених пунктів не враховуються розташовані в них установи відпочинку.

Наприклад, в селищі міського типу Білики Кобеляцького району Полтавської області персонал, що проживає тут та обслуговує розміщені поряд установи відпочинку (86 осіб), 
взагалі не включений в містобудівну групу, в результаті чого деякі функціональні діляники поселення в майбутньому виявляться меншими від необхідних.

Територіальне розміщення установ відпочинку здійснюється як за межами населених пунктів, так і безпосередньо в його межах. Обидва варіанти розміщення потребують функціональної, планувальної та композиційної єдності. Аналіз показує, що в проектах установ відпочинку, які розташовані за межами населених пунктів, зв'язок з ними не враховується взагалі (база відпочинку біля хутора Коломийцево Озеро та с. Руденківка Полтавської області та ін.).

В цих проектах, як в числі інших (будинки відпочинку с. Абазівка, санаторій с. Говтва та дачні утворення с. Малий Перевіз Полтавської області і т. д.), передбачається використання в якості обслуговуючого персоналу місцевого населення, хоча соціально-економічне обгрунтування та перелік необхідних містобудівних заходів щодо рішення цього питання не розроблені. Це може призвести в майбутньому до необгрунтованого відволікання частини працездатного населення від сільського господарства.

Допускається проектування на одній ділянці установ відпочинку дітей та дорослих без дотримання нормативних розривів. Під час будівництва на одній ділянці рекреаційних установ подібного профілю не планується створення комплексів з єдиної системою обслуговування, кооперація інженерних мереж передбачається лише в окремих проектах (бази відпочинку біля с. Омельник та с. Кам'яні Потоки Полтавської області тощо).
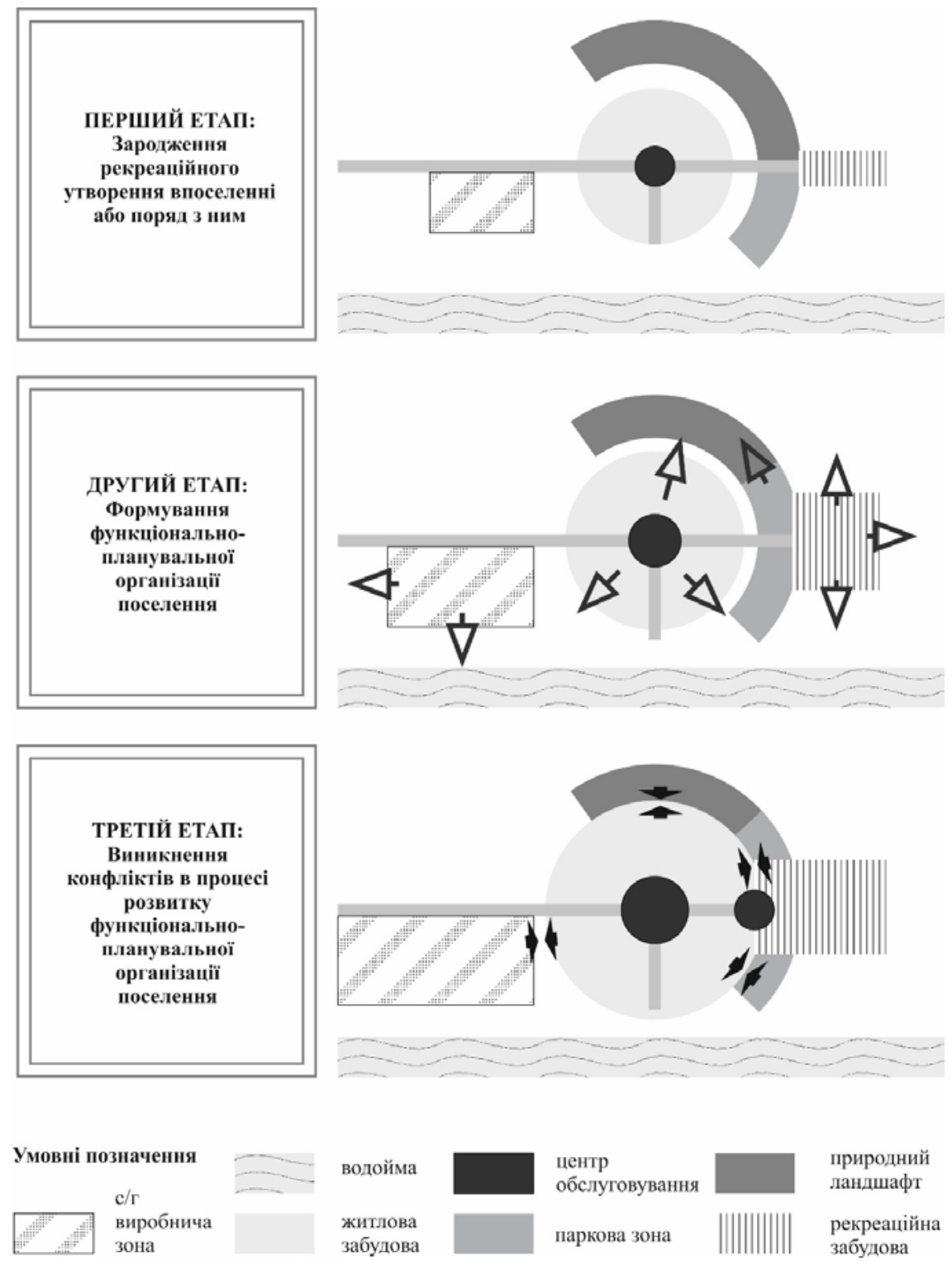

природний ландшафт

рекреаційна забудова

Рис. 1. Аналіз динаміки розвитку просторової структури населених пунктів з агрорекреачійною функиією. 
Існують приклади, коли при розміщенні установ відпочинку в межах сільського населеного пункту допускалися порушення санітарних розривів, склалося несприятливе функціональне зонування. Так, при проектуванні готельно-розважального комплексу в с. Клюсівка Полтавської області не врахована просторова організація населеного пункту, в результаті високі спальні корпуси частково порушили цілісність силуету поселення. Розселення обслуговуючого персоналу та розміщення комплексу складських об'єктів здійснено безпосередньо в курортній зоні, що обмежить можливість розвитку об'єкту в майбутньому та є несприятливим 3 точки зору санітарної охорони рекреаційних ресурсів.

Перераховані недоліки в проектуванні наразі обумовлені недосконалим відпрацюванням відповідної нормативної літератури. Незважаючи на те, що в методичній літературі зону рекреаційної забудови (зону проживання відпочиваючих) в будь-якому озернорічковому районі рекомендується створювати на територіях існуючих селиш та сіл або поблизу від них, пов'язуючи всі в один містобудівний комплекс, конкретні рекомендації з планування та забудови таких комплексів відсутні.

Висновки. Аналіз вітчизняного та закордонного проектного досвіду, теоретичних досліджень показує, що практично всюди використання малих населених пунктів для відпочинку визнано раціональним. Незважаючи на різноманітність підходів архітекторів та дослідників до поняття «поселення 3 агрорекреаційною функцією» та екологічним принципам його планувальної організації, архітектурного обліку, можна виділити ряд загальних положень:

- Екопоселення агрорекреаційного направлення є перспективним типом рекреаційного розвитку, відображуючи загальну тенденцію до дезурбанізації природного середовища.

- Екопоселення агрорекреаційного направлення, в залежності від конкретних умов, може існувати і як самостійне містобудівне утворення (агрорекреаційне екопоселення) та як частина поселення господарського використання (агрорекреаційна екомережа).

- В багатьох країнах отримала розповсюдження тенденція до створення агрорекреаційних утворень на базі малих населених пунктів з обмеженим містобудівним розвитком.

Завдяки загальним тенденціям можна виділити основні прийоми планування та забудови заміських рекреаційних установ в закордонній практиці. Тенденція створення рекреаційних утворень на базі малих населених пунктів з обмеженим містобудівним розвитком передбачає наступні варіанти використання поселень:

- Як основи для розміщення установ відпочинку зі збереженням та розвитком господарських функцій, збереженням постійного населення, частина якого зайнята обслуговуванням відпочиваючих;

- Як місця розміщення в структурі аграрного поселення дачних ділянок;

- Як місця розміщення відпочиваючих в невеликих готелях або безпосередньо в будинках місцевих жителів, які пристосовані для цих цілей;

- Як містобудівна основа для створення екологічно модернізованого середовища проживання відпочиваючих, без збереження господарських функцій (окрім народних промислів) з переселенням місцевого населення до сусідніх поселень або збереженням частини його для обслуговування відпочиваючих.

Найбільш перспективним для умов Полтавської області України представляється варіант рекреаційного розвитку малих населених пунктів як складової частини мережі агрорекреаційних поселень з використанням екологічних принципів проектування.

\section{ЛIТЕРАТУРА}

1. Alexis Howland. AGRO-AESTHETIC CITY [Електронний ресурс] // MIT. - 2011. - Режим доступу до pecypcy: http://cargocollective.com/mit/Agro-Aesthetic-City

2. Рекомендации по составлению схем и проектов районной планировки на основе системного анализа и программно целевого подхода ЦНИИП градостроительства. - М.: Стройиздат, 1988

3. Сайт Глобальної мережі Екопоселень [Електронний ресурс] - Global Ecovillage Network (GEN) Режим доступу: http://gen.ecovillage.org.

4. Гур'янова Г. А. Розвиток функції рекреації в сільському розселенні // Рекреаційні райони в групових систем розселення (оглядова інформація): ЦНТІ з цивільного будівництва та архітектури, вип. 2. М., 1980, с. 29-62.

5. Паунова Е. Архітектурній ансамбль села Боженці // Архітектура, №2, 1977.

6. Робев Р. Села та що недільний канікулярний відпочинок // Архітектура, № 3-4, Софія, 1973, с 28-34.

7. Cena A. Sudeska wies Letnis Kowa // Budiwnictwo Wiejskie. 1975. № 5. S. 10-11.

8. Zawistowska A. Tam, gdzie tworzy sie tradicie // Budiwnictwo Wiejskie. 1974. № 10. S. 12-14.

9. Кодин, В.А. (1988). Архитектурно-планировочная организация агрорекреационных поселений (на примере лесостепной зоны Украины): автореф. дис. канд. арх-ри 18.00.04 - Київ 